\title{
Teaching ergonomics to undergraduate physical therapy students: new methodologies and impressions of a Brazilian experience
}

\author{
Letícia Holtz Barbosa ${ }^{\mathrm{a},{ }^{*}}$ and Maria Helena Câmara Pinheiro ${ }^{\mathrm{b}}$ \\ a Physiotherapy Department, Centro Universitário Barão de Mauá, Rua Iguape,48, CEP:14090-092, Ribeirão \\ Preto, SP, Brazil \\ ${ }^{\mathrm{b}}$ Psycology Department, Universidade de Ribeirão Preto - UNAERP, Av. Costábile Romano, 2201, CEP:14096- \\ 900, Ribeirão Preto, SP, Brazil
}

\begin{abstract}
Being ergonomics a scientific discipline based on knowledge of several areas, it is important to use education methodologies that promote critical thinking and reflective during the educational process. The article discusses the importance of interdisciplinarity in undergraduate courses in health care in particular in disciplines that address the ergonomics issue. The aspects of the introduction of new education methodologies, as well as case studies in undergraduate courses in Brazil, are discussed in this study. Based on the literature review conducted, some proposals for action in the interdisciplinary teaching of ergonomics in Physiotherapy courses are presented.
\end{abstract}

Keywords: Interdisciplinarity, Ergonomics, Undergraduate, Physical Therapy, Brazil

\section{Introduction}

Nowadays, in the globalized world, the stimulus to change is constant in all aspects of human life, in this context can include education. However, looking at the process of teaching in Brazilian education, it is clear that between stimulus and change, there is a big difference. The teaching process was, and still is, heavily based on methods of classes, in which the teacher adopts a position of keeper of all knowledge and truth on a particular subject [10][27]. The content is transmitted so ready, already prepared and determined by the teacher.

This context encourages students to adopt an uncritical habit, passive and little participation in relation to their academic learning process [27]. This posture is very easy to identify in academia either by personal observations as reported by teachers and students. The formation of professional higher educa- tion has followed this pattern. Partly because of the lack of educational preparation of those who are teachers in higher education and partly by habit, rooted by students over the years of his educational background, ready to receive the information passively.

Based on these reflections is important to highlight the considerations of UNESCO on Education. The thesis defended by the report of the International Commission on Education for the XXI Century, became part of the guiding principles of educational policy. Therefore, education to respond to all of their missions, must be organized around four fundamental learning, which throughout life, are in some way to each individual, the pillars of knowledge, which are [6]:

- Learning to know, or rather acquire the instruments of understanding;

\footnotetext{
*Corresponding author. E-mail: lh_barbosa@yahoo.com.br.
} 
- Learn to do in order to act upon the environment in which it is inserted;

- Learning to live together in order to participate and cooperate with others in all human activities and;

- Learning to be, that integrates the three pillars before.

These axes must be permanent actions aimed at training the student as a person and citizen [6].

Currently the educational directives in Brazil [2] has led more and more educational institutions and teachers, in a joint action or not, to search for methodologies. These methodologies lead to the formation of a professional ready to meet the market demands and the globalized world in which we live.

Today we find the need to break away from traditional teaching models that are widely used [9]. When looking at the pillars of the new education system and considering the speed with which changes occur in knowledge and production, it is clear that interdisciplinarity is inserted as a new approach to teaching [9].

To understand the term interdisciplinarity, some considerations must be made, including the concept of discipline. Discipline is a selection of knowledge that are ordered with the support of a set of didactics and methodological procedures and the assessment of learning [9]. The organization of curriculums based on disciplines encourages fragmentation and compartmentalization of knowledge, making the learning difficult [21].

There are several theories and concepts involved in defining interdisciplinary. In this study was used the idea of interdisciplinarity as the interaction between two or more disciplines, which may range from a simple communication of ideas to the mutual integration of the concepts of education and research [7].

Thus, the concept of discipline combined with an interdisciplinary perspective, promotes understanding that the individually curricular disciplines signify that knowledge makes a cut of reality, to distinguish the parts and not separate them [23]. Looking this way, it is identified that is necessary to use strategies to establish an interactive relationship between the disciplines, which represent the foundation of interdisciplinary relations.

This proposal aims at the integration of related disciplines, which involves more than the exchange of information on objectives, content, procedures and bibliographies among teachers [25]. The implementation of interdisciplinarity requires that each expert or teacher beyond his own specialty, identifying their limits to receive contributions from other disciplines, on behalf of all [12]. It can be seen so that changes and adaptations are long processes that involve multiple instances of the school community [13]. Therefore, the actions in this regard are still far from representing the reality of higher education in Brazil [8].

All this context is directly reflected in the newly formed professional, which often finds difficult to solve the most demanding market requirements [20].

Being understood ergonomics as a "scientific discipline concerned with the understanding of interactions among humans and other elements of a system, and the profession that applies theory, principles, data and methods to design in order to optimize human well-being and overall system performance" [14], interdisciplinarity has become essential in this process.

For the interference of ergonomics in the workplace can be effective and result in improved well being of people and production, it is necessary to know several specific areas. Thus, the need to develop interdisciplinary teaching of ergonomics is due to the very formation of ergonomics as a profession. The content of various disciplines need to have communication between them. The content of various disciplines need to have communication between them. So the professional develop a more critical and reflective thinking about the reality of the community where it operates. Thus the actions will be most effective ergonomic.

The aim of this study was to address the importance of interdisciplinarity in teaching collegelevel courses in health care, as well as lay the groundwork for a proposed disciplinary action in teaching undergraduate courses in ergonomics.

\section{Method}

The bibliography was obtained through electronic and print research, regardless of the time of publication. The papers were served on the international and domestic data basis: PubMed, Lilacs, Scielo-Brasil and BIREME. The keywords used to search were: Competency-Based Education; Higher Education; Problem-Based Learning; Ergonomics; Attitudes, Practice, Physical therapy, Interdisciplinary Research; undergraduate, Interdisciplinary Communication.

Based on this literature review was prepared a proposal for possible interdisciplinary actions to be implemented in a discipline of ergonomics to courses of physical therapy. 


\section{Findings and Discussion}

According to the literature review conducted, it was found that in Brazil, some actions are implemented in an effort to change the reality of higher education courses in health care. Such situations are more common in medical courses [1]. However, no study described this methodology in discipline or specialization of ergonomics. Thus some of these situations will be described here attempts to illustrate the insertion of interdisciplinarity in courses of the health area, and will subsequently be raised aspects of its integration in the teaching of ergonomics.

In Brazil, between the currents educational theories based on criticism, the "pedagogy of liberation" has been the most used [2]. Some formation centers in the area of health insert within their curriculum the Problem-Based Learning (PBL) [22]. These methods work with problems for the development of teaching and learning processes [5].

According to Marin et al. [19], either PBL or pedagogy for liberation, are modalities that help to overcome the traditional model of education, in favor of a form of teaching and learning that considers the complexity which reality presents itself. One study [5] analyzed the two methods and showed that both may represent an innovative trend in the context of education in health.

Among the successful cases, identifies the change in the learning process of the School of Medicine, Harvard University (USA) [1]. In the late 70 a diagnosis was done by the academic community of this school and the results were very similar to the current Brazilian reality. They found an anonymous mass of students being overwhelmed by fragmented information that were transmitted in expositive classes of varying quality. All this, within a process that valued more memorization than critical thinking (ALDESTEIN; RAMOS, $1994^{1}$ apud Aguiar[1]). In 1985, the medical school curriculum had changed their strategies to PBL, the teaching-learning process was student-centered and the recovery of doctor-patient relationship.

It was identified that the prestige of this renowned school was not lost by focusing not only on research, but also become excellent on teaching. Among the

${ }^{1}$ ALDESTEIN, J.; RAMOS, M. (1994). Searching. In: TOSTESON, D., ALDESTEIN, J., CARVER, S. (Ed.). New Pathways to Medical Education: learning to learn at Harvard Medical School. Cambridge (MA): Harvard University Press, p.14-29. results, it was found that most tutors enjoyed his work, although the teaching is more complex today than ever before. In addition, more interaction with students and their rapid identification of professional and personal development were also sources of gratification for teachers [1].

Regarding the student, they demonstrate mastery in the relationship with patients, colleagues and situations-problems. In the pedagogical aspects, there is a balance between the biomedical base and the humanistic training of the physician. An important point for this success was the creation of another academic career that rewards leadership and excellence in teaching [18].

Other studies have reported some successful cases in Brazil, as in the Medical School of Marilia (FAMEMA) [16], [19] and the State University of Londrina (UEL) at the Center for Health Sciences (CCS) [15][17]. These universities have started their processes for modifying the teaching methodology in the 90 's.

A survey after 13 years of implementation of new methodologies in FAMEMA showed that in the view of students, active methods stimulate the constant study, independence and accountability; enable the integration of the biopsychosocial dimensions; prepare for work as a team and bring the patients and students near to the healthcare staff [19].

The curriculum change involves a series of actions and presents itself as a complex process, since it encloses the institution, teachers and students [28]. All this brings many challenges, such as breaking with traditional models of teaching and training health professionals with powers to recover the dimension of care and the relationship between humans [5].

Thus, for various reasons, the liberating education is not yet a reality in most cases the courses in the area of health in Brazil. But the difficulties of change, should not inhibit educators. Many movements have been made in individual areas or small groups, trying to wake up to this need.

An example of these actions was the study of Piccini et al. [24], involving the discipline of communitarian medicine of the course at the Faculty of Medicine, Federal University of Pelotas, Brazil. Some changes in the methodology of teaching of this discipline have been applied. A questionnaire was used to assess students' cognitive skills, which were applied at the beginning, the middle and the end of the course. The values were compared between the two groups prior to the modification and the four classes following the intervention. The results showed that cogni- 
tive growth in pre-intervention group was around $20 \%$, whereas in the post-intervention groups this value was $50 \%$ [24].

This study shows the need for deployment of innovative experiences to target. So that enable to test methods, techniques and instruments, avoiding initiatives that involve the whole school in processes that may pose a risk of failure too great or limited chances of success in real terms of transformation [24]. The study reinforces the importance of initial processes within traditional curricular structures, so that changes can be made gradually and consistently.

The successful application of interdisciplinary courses was shown in a study by a group of eighteen teachers considered innovative at the University of São Paulo (USP) [3].

These professors were interviewed to detail their innovative experiences and best explain the reasons why it had introduced changes to their way of teaching. The author [3], put in his article several interviews, among them one will be highlighted:

"... During a certain period of time I took my students to attend the factory permanently, because I thought that the concepts of planning and production control and the questions proposed in the books were far from the practice, since the daily life have variables that the book does not include (Joseph Benedict Sacoman in CHAMLIAN[3] p.57)."

This case report summarizes the idea proposed in this discussion. By showing that interdisciplinarity can lead students to a greater interaction with the market reality, and to develop a critical and analytical thinking more consistent with the new requirements. It is noteworthy that the actions have to happen so that later more appropriate attitudes will become reality.

Since ergonomics is a discipline that combines knowledge of other related areas, the problems appear to be very complex in most cases. Thus, if the training such as ergonomics, the student experience that inter-relationship in a practical way, the results of ergonomic interventions will be better and consequently there will be a greater recognition of the importance of this area.

Thinking about it, will be presented some proposals for action aimed at bringing an interdisciplinary approach in teaching of ergonomics.

The analysis from case studies raises some possible directions in order to implement changes in teaching methods [3][4][11][24][26][8] based on interdisciplinary. They are:

- The practice as a basis for theoretical reflection;
- The use of basic sciences as an ongoing complement of the development of professional contents;

- Lecture as a possible tool for learning;

- Teaching focused on the needs of the community or company;

- To promote pro active posture in the students;

- Assessment tools aimed to capture the knowledge, skills and attitudes of students with primary goal of guiding corrections needed trajectories;

- Change in the characteristics of the subjects, directing the student to more concrete experience of simulated or for scientific initiation;

- Development of courses in closely with the needs of the labor market, or using their own manufacturing facilities as a classroom;

- Overhaul of lab activities by proposing problems whose solutions are unknown even by their own teacher, introducing a question of actual research and not simulated;

- Using an exercise program by replacing the single final exam;

- Use of portfolio, making up the set produced in a discipline, including research reports, reflections of works, expectations of the course and the profession, self-reflection and selfevaluation;

- Work with small tutorial groups;

- Conducting workshops;

- Creation of laboratory of experiences;

- Case studies;

- Social movements of the course.

Some of these actions are being implemented in a discipline of ergonomics in a course of physiotherapy in the state of São Paulo. Preliminary results have been very effective, based on greater participation and student interest in topics covered in the course. More effective results can be presented in the future.

Teaching ergonomics in disciplines segmented or in forms of performance specific of certain professionals, will continue to enhance a false idea of what really means ergonomics actions. The ergonomist must understand these interactions between knowledge areas and among professionals, so that the ergonomic actions are understood by companies within their larger goals, bringing solutions that involve the improvement of health, worker safety and comfort, along with the increase in productivity. 


\section{References}

[1] Aguiar, A.C. (2001). Implementando as novas diretrizes curriculares para a educação médica: o que nos ensina o caso de Harvard? Interface - Comunic, Saúde, Educ., v.5, n.8, p.161-166.

[2] Brasil (1997). Secretaria de Educação Fundamental. A tradição pedagógica brasileira. In: Parâmetros Curriculares Nacionais. Brasília: MEC/SEF. p.30-33.

[3] Chamlin, H.C. (2003). Docência na universidade: professores inovadores na USP. Cadernos de Pesquisa, n. 118, p.41-64.

[4] Chun, R.Y.S. \& Bahia, M.M. (2009). O uso do portfólio na formação em fonoaudiologia sob o eixo da integralidade. Rev. CEFAC, v.11, n.4.

[5] Cyrino, E.G. \& Toralles-Pereira,M.L. (2004). Trabalhando com estratégias de ensino-aprendizado por descoberta na área da saúde: a problematização e a aprendizagem baseada em problemas. Cad. Saúde Pública, v.20, n.3, p.780-788.

[6] Delors, J.(org.) (2000). Educação: um tesouro a descobrir. Relatório para a UNESCO da Comissão Internacional sobre Educação para o Século XXI. 10.ed. São Paulo: Cortez; Brasília: MEC-UNESCO.

[7] Fazenda, I.C.A. (1979). Integração e interdisciplinaridade no ensino brasileiro: efetividade ou ideologia. São Paulo: Edições Loyola.

[8] FNEPAS- Fórum Nacional de Educação dos Profissionais da Área da Saúde (2008). Relatório final da oficina metodologias ativas como estratégia de formação para a integralidade do cuidado. Campinas, $38 \mathrm{p}$. Disponível em: $<$ http://www.fnepas.org.br/pdf/relatorio_fnepas_oficina meto dologia.pdf $>$. Acesso em: 16 nov. 2010.

[9] Fortes, C.C. (2009). Interdisciplinaridade: origem, conceito e valor. Revista acadêmica Senac on-line, Belo Horizonte, ed.6. Disponível em: <http://www3.mg.senac.be/Revistasenac/edições/Edicao6.htm $>$. Acesso em: 14 nov. 2010.

[10]Freire, P. (1987). Pedagogia do Oprimido. 17 ed. Rio de Janeiro: Paz e Terra.

[11] Galindo, A.G.; Ribeiro, F.C. \& Silva, M.C. (2010). Integração em bloco de disciplinas como alternativa para implementação de estratégias interdisciplinares. In: I Seminário de Interdisciplinaridade do Centro Superior de Ensino do Amapá, Macapá, Resumos... Disponível em: $<$ http://www.ceap.br/artigos/ART10022010190833.pdf>. Acesso em: 15 nov. 2010.

[12] Gusdorf, G. (1976). A agonia de nossa civilização. São Paulo: Convívio.

[13]HASS, C.M. (2007) Interdisciplinaridade: uma atitude docente. Olhar Docente, 1, pp. 179-193. Retrieved from http://redalyc.uaemex.mx/pdf/684/68410110.pdf.

[14] IEA (International Ergonomics Association). In The Discipline of Ergonomics. 2000. Retrieved from http://www.iea.cc/01 what/What\%20is\%20Ergonomics.html.
[15]Ito, A.M.Y.; Bogado, M.L.G.; Carvalho, S.R.Q.; Lavado, E.L.; Campos, J.B.; MORITA, M.C.; IVAMA, A.M. \& NUNES, E.F.P.A. (2010). As transformações curriculares dos cursos do CCS/UEL no contexto da nova LDB. Disponível em:

http://www.ccs.uel.br/olhomagico/N16/em questao.htm>. Acesso em 16 nov 2010.

[16]Komatsu, R.S (2006). Um olhar sobre a FAMEMA e o processo pioneiro de implementação da aprendizagem baseada em problemas. Cadernos ABEM, v.2, p.64-72.

[17] Lavado, E.L. (2010). Fisioterapia: flexível, rumo ao $3^{\circ}$ milênio. In: Ito, A.M.Y. et al. As transformações curriculares dos cursos do CCS/UEL no contexto da nova LDB. Disponível em:

$<\underline{\text { http://www.ccs.uel.br/olhomagico/N16/em questao.htm }>}$. Acesso em 16 nov.2010.

[18]Lovejoy, F.; Clark, M. (1995). A promotion ladder for teachers at Harvard Medical School: experience and challenges. Acad. Med., Washington, v.70, n.12, p.1079-86.

[19]Marin, M.J.S. et al. (2010). Aspectos das fortalezas e fragilidades no uso das Metodologias Ativas de Aprendizagem. Rev. Bras. Educ. Med., v.34, n.1, p-13-20.

[20]Mendes, M. \& Ghilhermeti, P. (2007). Fragmentação do saber e interdisciplinaridade na formação universitária. Revista eletrônica Lato-Sensu, 1, pp.1-12. Retrieved from http://www.unicentro.br.

[21] Morin, E. (2000). Os setes saberes necessários à educação do futuro. 2.ed. São Paulo: Cortez.

[22] Pereira, S.E. (2007). Contribuições para um planejamento educacional em ciências da saúde com estratégias inovadoras de ensino-aprendizagem. Com. Ciências Saúde, v.18, n.1, pp.33-44.

[23]Petraglia, I.C. (1993). Interdisciplinaridade: o cultivo do professor. São Paulo: Pioneira: Universidade São Francisco. $82 \mathrm{p}$.

[24]Piccini, R.X; Faleiros, J.J.; Faria, L.H. and Ceia, M.L. (2001). Disciplina de medicina comunitária: relato de uma experiência inovadora. Rev. Bras. Educ. Med., v.25, n.2, p.64-69.

[25] Pires M.F.C. (1998). Multidisciplinaridade, interdisciplinaridade e transdisciplinaridade no ensino. Interface: Comunic, Saúde, Educ, Botucatu, v.2, n.2, p.173182.

[26] Ribeiro, M.L. and Cunha, M.I. (2010). Trajetórias da docência universitária em um programa de pós-graduação em Saúde Coletiva. Interface - Comunic., Saude, Educ., v.14 n.32, pp.55-68.

[27] Stacciarini, J.M.R. and Esperidião, E. (1999). Repensando estratégias de ensino no processo de aprendizagem. Rev.latinoam.enfermagem, v. 7, n. 5, p. 59-66.

[28]Vignochi et al. (2009). Considerações sobre aprendizagem baseada em problemas na educação em saúde. Rev. HCPA, v.29, n.1, p.45-50. 